diverticular disease then the dietary theory would not explain the occurrence of the disease in five young patients in this series.

Possibly the most important factor in diagnosing diverticular disease is the availability of radiological facilities. As the population coverage of health services in Kenya is rot expected to reach even $50 \%$ by $1984^{5}$ very few people are likely to undergo barium-enema examination. This is especially true of elderly people (those most at risk), who live largely in rural areas.

It is expected that as more barium-enema examinations are carried out more cases will come to light.

I thank Professor Alexander Margulis, of the University of California, San Francisco, for reviewing the films.

${ }^{1}$ Painter, N S, and Burkitt, D P, British Medical fournal, 1971, 2, 450.

2 Calder, J F, and Wasunna, A E O, East African Medical fournal, 1978, $55,579$.

${ }^{3}$ Manousos, O N, Truelove, S C, and Lumsden, K, British Medicalfournal, $1967,3,762$.

- Burkitt, D P, Lancet, 1969, 2, 1229.

5 Were, M K, East African Medical fournal, 1977, 54, 524.

(Accepted 4 April 1979)

University Department of Diagnostic Radiology, Kenyatta National

Hospital, Nairobi, Kenya

JOHN F CALDER, MB, FRCR, senior lecturer

\section{Intact removal of phytobezoar using fibreoptic endoscope in patient with gastric atony}

Phytobezoars are concretions of vegetable material in the gastrointestinal tract. They carry a high risk of complications, ${ }^{1}$ so that removal is advisable. Formerly gastrotomy was required but recently medical methods of treatment proving effective have included enzymatic digestion and endoscopic fragmentation. ${ }^{2}$

\section{Case report}

A 58-year-old man with longstanding ischaemic heart disease was admitted with chest pain. His treatment included metoprolol, glyceryl trinitrite, and perhexiline. For nine months he had been impotent and had episodic diarrhoea and peripheral paraesthesia without objective sensory loss. He also gave a seven-month history of anorexia and twice-weekly episodes of crampy epigastric pain relieved by vomiting. On questioning he admitted consuming large quantities of alcohol over several decades. He would also eat an orange each day, the peel of which he would swallow in quarters without mastication.

Barium-meal examination showed a mobile mass in the antrum. Gastroscopy was performed using an Olympus GIF-D3 panendoscope, which disclosed an orange-coloured bezoar wedged in the pylorum (figure). A polypectomy snare was passed around the bezoar, which was then withdrawn with the endoscope. Oesophagogastroduodenoscopy was performed immediately, the only abnormality noted being mild inflammation around the pylorus. The bezoar measured $7 \times 3 \mathrm{~cm}$ and histologically was shown to consist of vegetable fibre. After removal of the phytobezoar the patient reported a dramatic return in appetite.

Investigations showed raised activities of serum transaminases, alkaline phosphatase, and $\gamma$-glutamyl transferase. The hospital records had shown intermittently raised activities of the serum transaminases dating back some 18 months, which had become more pronounced after perhexiline treatment was begun 14 months before the bezoar was removed. Bromsulphthalein excretion was also impaired, with $6 \%$ remaining at 45 minutes (normal $<3 \%$ ). Glucose tolerance was normal. Gastric emptying (after removal) of an isotopically labelled mixed liquid (milk) and solid (egg) meal was extremely slow. The percentages remaining in the stomach 70 minutes after eating were $52.7 \%$ for milk and $97.2 \%$ for egg, both considerably higher than normal values. ${ }^{3}$

\section{Comment}

With the exception of the persimmon variety, phytobezoars co:sist of fibrous cellulose glued together by a proteinaceous cement. ${ }^{4}$ Our patient regularly swallowed large segments of orange pith without mastication, thereby supplying the components. Impaired gastric emptying is also relevant to the formation of phytobezoars, which occur most frequently after gastric surgery, especially when vagotomy is

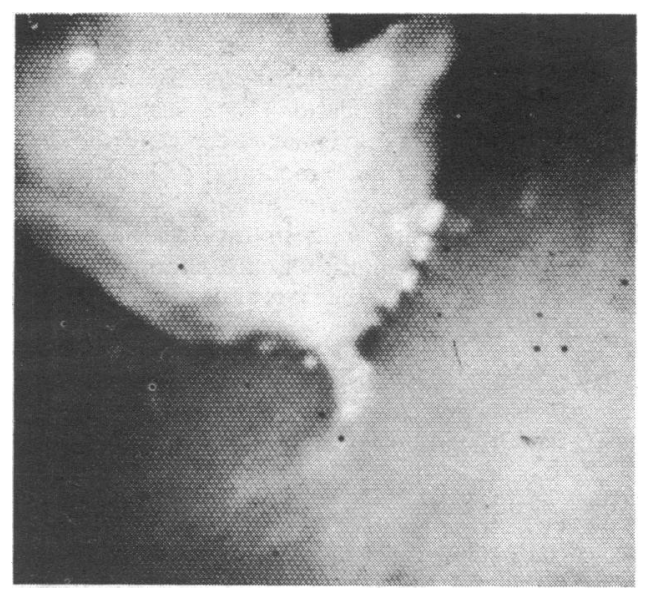

Endoscopic photograph of phytobezoar wedged in pylorus.

performed. ${ }^{1}$ This patient did not undergo gastric surgery and had no organic obstruction of the gastric outlet, yet clear gastric retention was shown after a mixed meal.

The reason for this gastric atony is not clear. Perhexiline may cause peripheral neuropathy and impotence. ${ }^{4}$ This patient complained of paraesthesia, impotence, and diarrhoea, possibly reflecting an autonomic neuropathy induced by perhexiline. His intake of large quantities of alcohol, however, may also be relevant, since alcoholics show disturbances of gastrointestinal motility similar to those found in diabetics. ${ }^{5}$ Some abnormality in hepatic function predated the perhexiline treatment yet may have been aggravated by the drug. ${ }^{4}$

Endoscopy has bee. used to diagnose and fragment bezoars, ${ }^{2}$ but we have been unable to find any reports in English of the successful removal of an intact gastric bezoar using our method. The shape, size, and fairly soft consister.cy made this phytobezoar a likely candidate for snaring. There would be considerable risk, however, in removing larger or more rigid bezoars using this method. In any case, bezoarectomy is a further possible endoscopic procedure.

${ }^{1}$ Raffin, S, in Gastrointestinal Disease, ed M H Sleisenger and J S Fordtran, ch 49, p 616. Philadelphia, W B Saunders, 1973.

2 Wortzel, E, Ferrer, J P, and De Luca, R F, American fournal of Gastroenterology, 1977, 67, 565 .

${ }^{3}$ Ostick, D G, Howe, K, and Cowley, D J, British fournal of Surgery, 1976, 63, 159.

4 Martindale: The Extra Pharmacopoea, ed A Wade, 27th edn, p 1655. London, Pharmaceutical Press, 1977.

${ }^{5}$ McNally, E F, Reinhard, A E, and Schwartz, P E, American fournal of Digestive Diseases, 1969, 14, 163

\section{(Accepted 6 April 1979)}

Queen's University, Belfast BT12 6BJ

J C MCLOUGHLIN, MD, MRCP, senior tutor, department of medicine

A H G LOVE, MID, FRCP, professor of gastroenterology

Royal Victoria Hospital, Belfast

A A J ADGEY, MD, FRCP, consultant cardiologist

A D GOUGH, FFR, consultant radiologist

M P S VARMA, PHD, MRCP, senior registrar in cardiology

ONE HUNDRED YEARS AGO In a memoir presented to the Academy of Sciences and Literature of Lyons, Dr Henry $\mathrm{H}$ Dor, a well-known oculist, contests the view held by Mr Gladstone, and by Geiger and Magnus of Boston, that our ancestors were colour-blind: a view deduced from their writings and from the different names which they have given to colours. Dr Dor endeavours to demonstrate that now, as in the time of Homer, poets insist too little upon the indications of the colours, but much more upon their luminous intensity. Moreover, $M$ Dor says that persons who do not possess any knowledge of physics find much difficulty in distinguishing the colours of the rainbow, and only see in it three or four colours, in place of the seven classical colours of its composition. Further, it results even from the very study of the Assyrian and Egyptian monuments, that those nations had not only perceived, but imitated, the greater part of the colours of which we are at present cognisant. (British Medical fournal, 1879.) 